\title{
INFLUENCE OF THE CUTTING PARAMETERS ON THE SURFACE ROUGHNESS WHEN MACHINING HARDENED STEEL WITH CERAMIC AND PCBN CUTTING TOOLS
}

\author{
Gabriel BENGA ${ }^{1, a^{*}}$, Danut SAVU ${ }^{1, b}$, Adrian Olei $i^{1, c}$ \\ ${ }^{1}$ University of Craiova, Faculty of Mechanics, Department of Engineering and Management of \\ Technological Systems, Calugareni Street No.1, Drobeta Turnu Severin, 220037, Romania \\ a gabrielbenga@yahoo.com, b danut.savu@ymail.com, ${ }^{\mathrm{c}}$ adrian_olei@yahoo.com
}

Keywords: hard turning, surface roughness, PCBN, ceramics, cutting parameters

\begin{abstract}
The paper presents the influence of various cutting regimes on the surface roughness, when a hardened bearing steel has been machined using both ceramic and PCBN cutting tools. There were used different cutting conditions varying cutting speed, feed rate and depth of cut in order to determine the influence of each cutting parameter on the surface finish.
\end{abstract}

\section{Introduction}

Nowadays there are many finishing operations where precision hard turning provides a viable alternative to grinding. Therefore hard turning could be considered as a possible replacement for grinding even though the grinding operation offers better precision and tighter tolerances. Nevertheless considering the latest developments in terms of precision for the new CNC lathes and tooling the benefits of hard turning such as, higher productivity, shorter cycle times outweigh these possible shortcomings. One of the main goals in precision hard turning is to minimize the tool wear in order to maintain as long as possible a sharp cutting edge, which will enable to obtain a high level of surface finish and dimensional precision of the machined surface. One of the most specified customer requirements is related to surface roughness [1]. Compared with grinding operation, precision hard turning enables high material removal rate, lower energy consumption, greater process flexibility, which makes it very attractive to automotive and bearing industry $[2,3]$. The development of new cutting tools as: PCBN, polycrystalline diamond and various types of ceramic cutting tools made possible the replacement of the grinding operations with hard turning operations. Winands [4] pointed out that the energy consumption for removing a certain quantity of metal using hard turning represents at most $10 \%$ of the value required for grinding. However, the major challenge is to maintain surface finish and dimensional accuracy with a reasonably long tool life. Many researchers [5, 6, 7] have investigated the performance and the wear behavior of different PCBN and ceramic tools in finish turning.

\section{Materials and experimental procedure}

The tests were performed on a CNC lathe $(5,5 \mathrm{~kW}$ and $3600 \mathrm{rpm})$ using triangle inserts of Sandvik Coromant CC650 mixed alumina $-\mathrm{Al}_{2} \mathrm{O}_{3}+$ Tic, CC670 whiskers reinforced alumina and CB 7020 polycrystalline cubic boron nitride

The geometry for all inserts used was TNGN 160408T01020 attached to a tool holder coded CTGNR 2525 MID. The workpiece material consisted in tubes of DIN 100Cr6 bearing steel hardened and tempered to 60-62 HRC, divided in eight sections. Each section from a tube was machined using a different cutting regime as follows:

$\mathrm{R} 1: \mathrm{Vc}=100 \mathrm{~m} / \mathrm{min}, \mathrm{f}_{\mathrm{n}}=0,06 \mathrm{~mm} / \mathrm{rev}, \mathrm{a}_{\mathrm{p}}=0,5 \mathrm{~mm}$;

$\mathrm{R} 2: \mathrm{Vc}=100 \mathrm{~m} / \mathrm{min}, \mathrm{f}_{\mathrm{n}}=0,22 \mathrm{~mm} / \mathrm{rev}, \mathrm{a}_{\mathrm{p}}=0,5 \mathrm{~mm}$;

R3: $\mathrm{Vc}=180 \mathrm{~m} / \mathrm{min}, \mathrm{f}_{\mathrm{n}}=0,06 \mathrm{~mm} / \mathrm{rev}, \mathrm{a}_{\mathrm{p}}=0,5 \mathrm{~mm}$;

$\mathrm{R} 4: \mathrm{Vc}=180 \mathrm{~m} / \mathrm{min}, \mathrm{f}_{\mathrm{n}}=0,22 \mathrm{~mm} / \mathrm{rev}, \mathrm{a}_{\mathrm{p}}=0,5 \mathrm{~mm}$;

$\mathrm{R} 5: \mathrm{Vc}=100 \mathrm{~m} / \mathrm{min}, \mathrm{f}_{\mathrm{n}}=0,06 \mathrm{~mm} / \mathrm{rev}, \mathrm{a}_{\mathrm{p}}=0,25 \mathrm{~mm}$; 
R6: $\mathrm{Vc}=100 \mathrm{~m} / \mathrm{min}, \mathrm{f}_{\mathrm{n}}=0,22 \mathrm{~mm} / \mathrm{rev}, \mathrm{a}_{\mathrm{p}}=0,25 \mathrm{~mm}$;

$\mathrm{R} 7: \mathrm{Vc}=180 \mathrm{~m} / \mathrm{min}, \mathrm{f}_{\mathrm{n}}=0,06 \mathrm{~mm} / \mathrm{rev}, \mathrm{a}_{\mathrm{p}}=0,25 \mathrm{~mm}$;

$\mathrm{R} 8$ : $\mathrm{Vc}=180 \mathrm{~m} / \mathrm{min}, \mathrm{f}_{\mathrm{n}}=0,22 \mathrm{~mm} / \mathrm{rev}, \mathrm{a}_{\mathrm{p}}=0,25 \mathrm{~mm}$;

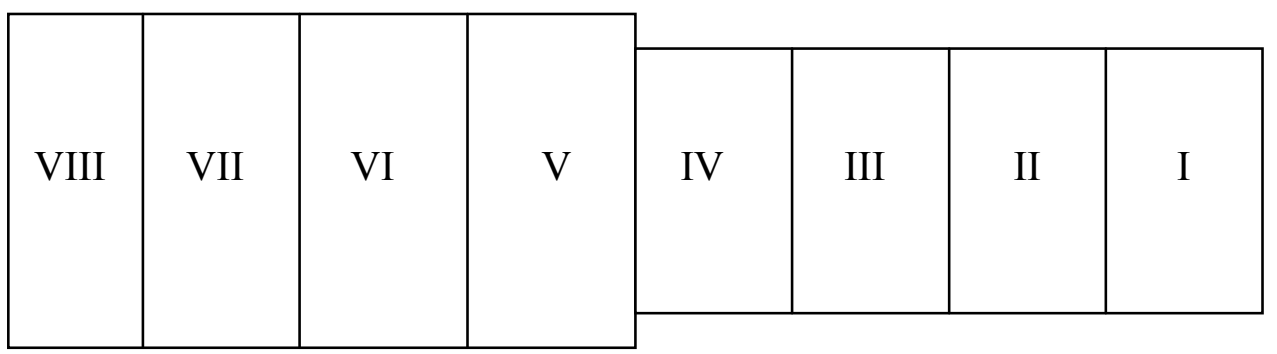

Figure 1. The workpiece material divided in 8 sections

Figure 1 shows how the workpiece material was divided in 8 sections. Each cutting regime was performed using new inserts with $\mathrm{V}_{\mathrm{B}}=0$. The surface finish for each section was measured using a Perthometer S4P V2.2 roughness meter.

\section{Results and discussions}

The values for surface roughness when the first cutting regime R1 was employed are presented in the following figures for the ceramic cutting tool materials and the polycrystalline cubic boron nitride tool used.

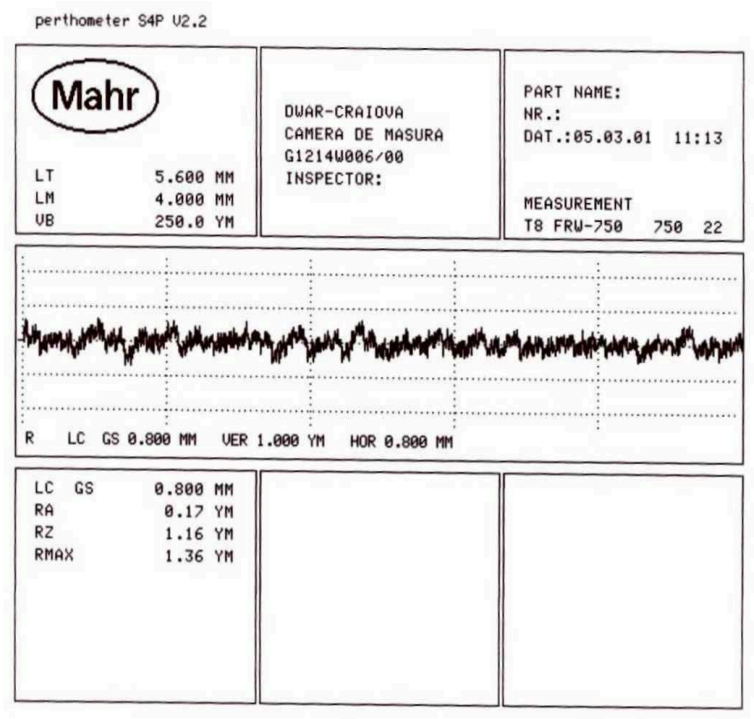

Figure2. Surface finish when R1 cutting regime and CC670 cutting tool was used $R a=0.17 \mu \mathrm{m}$

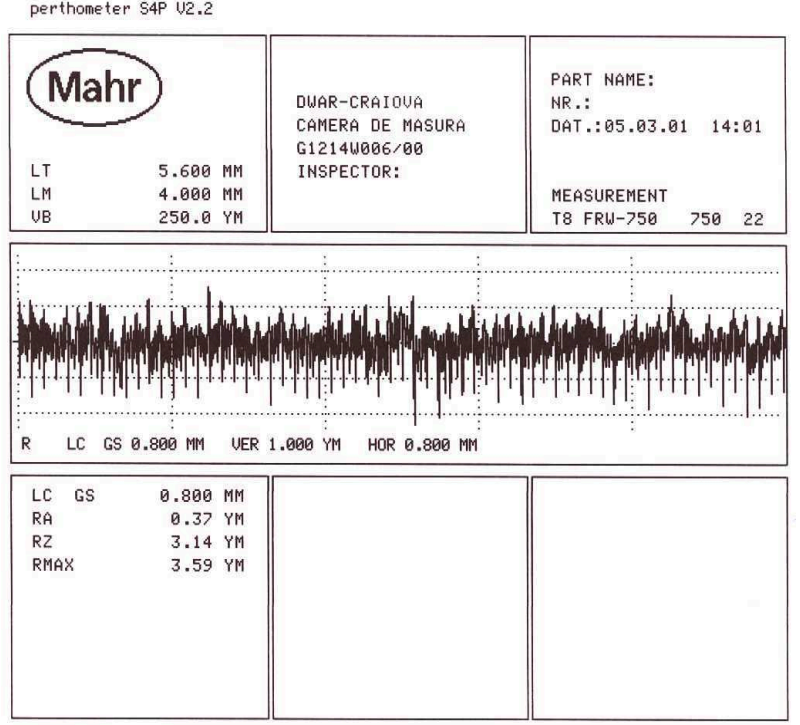

Figure3. Surface finish when $R 1$ cutting regime and CC650 cutting tool was used $R a=0.37 \mu \mathrm{m}$ 


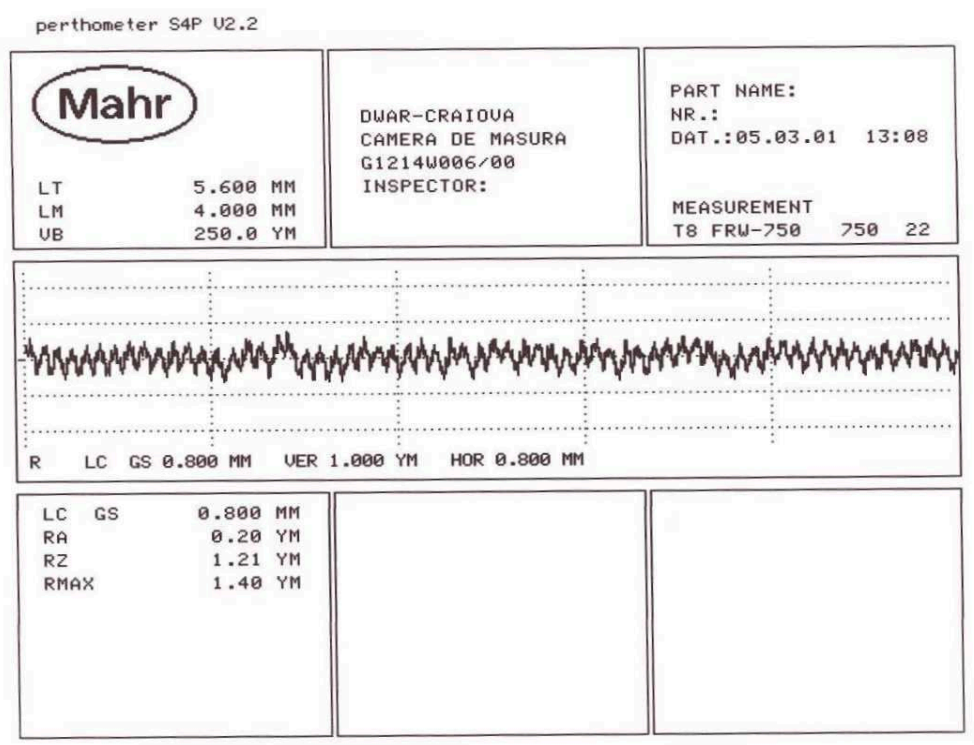

Figure 4. Surface finish when Rl cutting regime and CB7020 cutting tool was used $R a=0.20 \mu \mathrm{m}$

According to the above-presented figures it appears that the surface finish for CC670 $(\mathrm{Ra}=0.17 \mu \mathrm{m})$ and $\mathrm{CB} 7020(\mathrm{Ra}=0.20 \mu \mathrm{m})$ have very close values, while the surface finish value for the CC650 is almost double $(\mathrm{Ra}=0.37 \mu \mathrm{m})$

The surface finish values recorded for all the cutting regimes employed are presented in the table below.

Table1. Surface finish values recorded when different cutting regimes were used with three various cutting tool materials

\begin{tabular}{|l|c|c|c|}
\hline Cutting tool material & CC670 & CC650 & CB7020 \\
\hline Cutting regime & & & \\
\hline $\mathrm{R} 1: \mathrm{Vc}=100 \mathrm{~m} / \mathrm{min}, \mathrm{f}_{\mathrm{n}}=0,06 \mathrm{~mm} / \mathrm{rev}, \mathrm{a}_{\mathrm{p}}=0,5 \mathrm{~mm}$ & $0.17 \mu \mathrm{m}$ & $0.37 \mu \mathrm{m}$ & $0.12 \mu \mathrm{m}$ \\
\hline $\mathrm{R} 2: \mathrm{Vc}=100 \mathrm{~m} / \mathrm{min}, \mathrm{f}_{\mathrm{n}}=0,22 \mathrm{~mm} / \mathrm{rev}, \mathrm{a}_{\mathrm{p}}=0,5 \mathrm{~mm}$ & $1.66 \mu \mathrm{m}$ & $2.04 \mu \mathrm{m}$ & $1.21 \mu \mathrm{m}$ \\
\hline $\mathrm{R} 3: \mathrm{Vc}=180 \mathrm{~m} / \mathrm{min}, \mathrm{f}_{\mathrm{n}}=0,06 \mathrm{~mm} / \mathrm{rev}, \mathrm{a}_{\mathrm{p}}=0,5 \mathrm{~mm}$ & $0.21 \mu \mathrm{m}$ & $0.20 \mu \mathrm{m}$ & $0.18 \mu \mathrm{m}$ \\
\hline $\mathrm{R} 4: \mathrm{Vc}=180 \mathrm{~m} / \mathrm{min}, \mathrm{f}_{\mathrm{n}}=0,22 \mathrm{~mm} / \mathrm{rev}, \mathrm{a}_{\mathrm{p}}=0,5 \mathrm{~mm}$ & $1,74 \mu \mathrm{m}$ & $1,94 \mu \mathrm{m}$ & $1,21 \mu \mathrm{m}$ \\
\hline $\mathrm{R} 5: \mathrm{Vc}=100 \mathrm{~m} / \mathrm{min}, \mathrm{f}_{\mathrm{n}}=0,06 \mathrm{~mm} / \mathrm{rev}, \mathrm{a}_{\mathrm{p}}=0,25 \mathrm{~mm}$ & $0.24 \mu \mathrm{m}$ & $0.37 \mu \mathrm{m}$ & $0.17 \mu \mathrm{m}$ \\
\hline $\mathrm{R} 6: \mathrm{Vc}=100 \mathrm{~m} / \mathrm{min}, \mathrm{f}_{\mathrm{n}}=0,22 \mathrm{~mm} / \mathrm{rev}, \mathrm{a}_{\mathrm{p}}=0,25 \mathrm{~mm}$ & $1.74 \mu \mathrm{m}$ & $1.89 \mu \mathrm{m}$ & $1.21 \mu \mathrm{m}$ \\
\hline $\mathrm{R} 7: \mathrm{Vc}=180 \mathrm{~m} / \mathrm{min}, \mathrm{f}_{\mathrm{n}}=0,06 \mathrm{~mm} / \mathrm{rev}, \mathrm{a}_{\mathrm{p}}=0,25 \mathrm{~mm}$ & $0.26 \mu \mathrm{m}$ & $0.21 \mu \mathrm{m}$ & $0.20 \mu \mathrm{m}$ \\
\hline $\mathrm{R} 8: \mathrm{Vc}=180 \mathrm{~m} / \mathrm{min}, \mathrm{f}_{\mathrm{n}}=0,22 \mathrm{~mm} / \mathrm{rev}, \mathrm{a}_{\mathrm{p}}=0,25 \mathrm{~mm}$ & $1.66 \mu \mathrm{m}$ & $1.83 \mu \mathrm{m}$ & $1.19 \mu \mathrm{m}$ \\
\hline
\end{tabular}

Comparing the results obtained for R1 and R2 cutting regimes as well as the results obtained with other pairs of cutting regimes R3 and R4, R5 and R6, R7 and R8 it is obvious that an increasing of feed rate from $0.06 \mathrm{~mm} / \mathrm{rev}$ to $0.22 \mathrm{~mm} / \mathrm{rev}$ leads to a significant increase of surface roughness of about 8-10 times, irrespective of the values of the cutting speed and depth of cut.

In order to appreciate the influence of the cutting speed on the surface finish the following pairs of cutting regimes should be analyzed: $\mathrm{R} 1$ and $\mathrm{R} 3, \mathrm{R} 2$ and $\mathrm{R} 4, \mathrm{R} 5$ and $\mathrm{R} 7, \mathrm{R} 6$ and $\mathrm{R} 8$. It appears that increasing the cutting speed from 100 to $180 \mathrm{~m} / \mathrm{min}$ no matter if the feed rate is $0.06 \mathrm{~mm} / \mathrm{rev}$ or $0.22 \mathrm{~mm} / \mathrm{rev}$ and depth of cut is $0.25 \mathrm{~mm}$ or $0.5 \mathrm{~mm}$ does not bring a significant change in surface roughness. An exception is the CC650, which provide a better surface finish $(\mathrm{Ra}=0.20 \mu \mathrm{m})$ when $\mathrm{R} 3$ 
cutting regime was used that when $\mathrm{R} 1$ was employed $(\mathrm{Ra}=0.37 \mu \mathrm{m})$. These results come to confirm that variation of the cutting speed is not a major factor of influence for surface finish for all cutting tool materials used whether they are ceramics or PCBN.

The influence of the depth of cut on the surface finish can be assessed comparing the following cutting regimes: R1 and R5, R2 and R6, R3 and R7, R4 and R8. Analyzing all the pairs of cutting regimes mentioned above it can be concluded that depth of cut does not play a significant role in influencing the surface finish for all cutting tool materials used.

In terms of cutting tool materials influence on the surface roughness, it appears that PCBN cutting tool provides a better surface roughness that the ceramic tools.

\section{Conclusions}

The factor that has a major influence on the surface finish is the feed rate. Cutting speed and depth of cut basically do not affect the surface finish, at least for the workpiece material analyzed (100Cr6). Analyzing all the three cutting tool materials involved in the turning process it appears that the PCBN cutting tools were able to provide a better surface finish for most of the eight cutting regimes employed. One possible explanation could be the fact that PCBN cutting tools usually have a much better thermal conductivity than ceramics, which allow them to dissipate the heat faster than ceramics. Therefore PCBN cutting tools can maintain for a longer period than ceramics a cutting edge unaffected by the thermal processes that are usually present in a machining process.

\section{References}

[1] Saini, S., Ahuja, I.S., Sharma, V.S.: Influence of Cutting Parameters on Tool Wear and Surface Roughness in Hard Turning of AISI H11 Tool Steel using Ceramic Tools. Int. Journal of Precision Engineering and Manufacturing, Vol. 13, No.8, pp1295-1302, Springer, DOI 101007/s12541-0120172-6, 2012

[2] Klimenko, S.A., Mukovoz, Y.U., Polonsky, L.G. Advanced ceramic tools for machining applications, Key Engineering Materials, vol. 114, Zurich, 1996.

[3] Jeffrey, D., Shreyes, N.M. Effect of cutting edge geometry and workpiece hardness on surface residual stresses in finish hard turning of AISI 52100 steel, MED. Vol10, Manufacturing Science and Engineering, ASME 10, pp. 805-979, 1999

[4] Winands, N. Hartdrehen aus der Umformwarme geharteter Walzlageringe, Dissertation, RWTH, Aachen, 1996.

[5] Chou, Y.K., Evans, C.J., Barash, M.M. Experimental investigation on cubic boron nitride turning of hardened AISI 52100 steel, Journal of Materials processing Technology, vol 134, pp. $1-9,2003$.

[6] Konig, W., Berktold, A., Koch, K.F. Turning versus grinding: a comparison of surface integrity aspects and attainable accuracies, Annals of the CIRP, 42(1), , pp. 39-43,1993.

[7] Grzesik, W.: Wear of ceramic tools in hard machining, Journal of Achievements in Materials and Manufacturing Engineering, Vol. 26, Issue 2, pp. 127-130, 2008 